Компаративні досліАження слов'янських мов і Аітератур. 2019. Випуск 35

89]. Акрамя таго, кампаратыўныя формы могуць сустракацца ў складаназалежных сказах 3 даданымі супастаўляльнымі часткамі: Чым далей у лес, тым гусией [Belaruskiya 2004: 187]; Чымм далей у наш лес, тымм горай для эс-эс [Belaruskiya 2004: 57]; Чым больш нагаворыш, тым больш намыляешся [Belaruskiya 2004: 163].

Такім чынам, параўнальныя канструкцыі вызначаюцца трапнасцю, глыбінёй і ёмістасцю мастацкага абагульнення, а таму параўнанне валодае вялікай сілай эмацыянальнага ўздзеяння. Беларускія прыказкі і прымаўкі як разнавіднасць фальклору - эстэтычная спадчына многіх пакаленняў. Гэта частка тых духоўных багаццяў, якія выпрацавала за стагоддзі і тысячагоддзі чалавецтва і якія нам неабходна засвоіць.

\title{
REFERENCES:
}

1. Belaruskiya prykazki, prymauki, phrasealagismy (2004) / sclad. F. Yankouski, Minsk: Bel. navuka, 494 p. (Bel.)

2. Ragojsha, V.P. (2004). Paetychny slounik / V.P. Ragojsha, Minsk: Bel. navuka, 576 p. (Bel.)

Шариньова В. к.філол.н., доц., Могильовський університет імені А.А.Кулешова (Республіка Білорусь) Sharshniova $V$. PhD., docent, Mogilev State A.A. Kuleshov University (Republic of Belarus)

\author{
ДЫЯЛАГІЧНАЕ АДЗІНСТВА \\ ЯК СРОДАК СТВАРЭННЯ ПАДТЭКСТУ \\ (НА МАТЭРЫЯЛЕ МАСТАЦКІХ ТВОРАЎ У. КАРАТКЕВІЧА)
}

\section{DIALOGICAL UNITY AS A MEANS OF CREATING SUBTEXT (BY THE MATERIAL OF V. KOROTKEVICH'S WORKS OF ART)}

У статті йдеться про можливість стилізованого художнього діалогу містити імплічитну інформачію. Причому підтекст може бути виражений як безпосередньо самої діалогічної формою, так і використаними при передачі мови 
образними засобами. Вираз підтекстової інформації в діалогічних єдності $\epsilon$ важливою особливістю художніх творів В. Короткевича і впливає на формування його індивідуального авторського стилю. У художніх творах В. Короткевича діалог виявлясться смисловим центром, який визначає ідеологічну модальність розповіді, допомагає визначенню напрямів його розгортання.

Ключові слова: підтекст, імпліцитний, діалог, діалогічна єдність, текст, художній.

The article deals with the possibility of stylized artistic dialogue to contain implicit information. And the subtext can be expressed directly as the most dialogical form, and used in the transmission of speech figurative means. The two-dimensional nature of the subtext directs to its most successful location in the Dialogic speech, as the combination of the character's inner speech with the author's ensures the coexistence of two storytelling plans at the same time and significantly enhances the expressiveness of the narrative. The expression of subtext information in dialogical units is an important feature of $V$. Korotkevich's works of art and influences the formation of his individual author's style. In the works of art. Korotkevich's dialogue turns out to be a semantic center, which sets the ideological modality of the narrative, helps to determine the directions of its deployment (and thus contributes to the implementation of retrospective and prospectus communication, which is very important for all text categories, and especially-cohesion), helps to create the necessary semantic space for the author, in which the discourse will unfold.

Key words: subtext, implicit, dialogue, dialogical unity, the text of art.

Пастаноўка праблемы. Мастацкі дыялог, па сутнасці, уяўляецца як спецыфічная пісьмова зафіксаваная структурна-семантычная канструкцыя, якая будуецца паводле нормаў пісьмовага літаратурнага твора, г.зн. адпавядае патрабаванням яго ўнутранай і знешняй арганізацыі (кампазіцыі і архітэктонікі); замацоўвае ў мастацкім тэксце псіхалагічныя, кагнітыўныя i сацыякультурныя ўстаноўкі зносін, уласцівыя для пэўнай эпохі; адлюстроўвае сувязі паміж персанажамі твора, паміж персанажамі i аўтарам, паміж аўтарам і чытачом. Своеасаблівасць мастацкага тэксту як камунікацыйна накіраванага вербальнага твора, які валодае эстэтычнай каштоўнасцю, якраз і заключаецца ў яго здольнасці несці дадатковую, няяўную, так званую міжрадковую інфармацыю, увасабляючы ў вобразнай форме змадэляваную аўтарам асобую мастацкую карціну свету. 
Компаративні досліАження слов'янських мов і Аітератур. 2019. Випуск 35

Паслядоўнасць арганізацыі дыялагічнага адзінства (дыялагічных адзінстваў) можа быць важным сродкам канцэнтрацы і перадачы імпліцытнага зместу, што пацвярджаецца на прыкладзе мастацкіх твораў У. Караткевіча.

Сувязь 3 важнымі навуковымі заданнямі.Тэма даследавання непасрэдна звязана 3 агульнакафедральнай тэмай "Мастацкі тэкст у функцыянальным, прагматычным, кагнітыўным і метадычным аспекце”.

Аналіз навуковых крыніц. Наяўнасць непрамой, глыбіннай, скрытай інфармацы ўласціва як для вуснага, так і для стылізаванага пісьмовага маўлення. “Скрыты сэнс выказвання, які вынікае $з$ суадносін слоўнага значэння з кантэкстам і асабліва - маўленчай сітуацыяй”[NikoljukinA.N. 2003: 755]у філалагічных даследаваннях называецца падтэкстам. Дадатковы, няяўны імпліцытны змест пачынае ўспрымацца тады, калі ў адпаведнай маўленчай сітуацыі словы набываюць здольнасць перадаць такі аб'ём інфармацыі, які ў выпадку ізаляванасці слова мець проста не можа. 3'яўляючыся аспектам семантычнай структуры тэксту, падтэкст прызначаны для інтэлектуальнага ўспрыняцця, якое падразумявае асэнсаванне як павярхоўнага, так і глыбіннага зместу. Падтэкст так ці інакш звязаны з формай выражэння думкі, мае вытворны характар і можа стаць даступным толькі праз спецыяльна арганізаваны тэкст.

У лінгвістычных даследаваннях сярод сродкаў фарміравання падтэксту часта называюць усе тропы, стылістычныя фігуры, а таксама іншыя агульныя і прыватныя прынцыпы тэкстаўтварэння (такія, як, напрыклад, кантраст, асацыяцыя). Прыёмы выразнасці абапіраюцца на нечаканую лексічную спалучальнасць або парушэннемоўнай нормы 3 мэтай прыцягнення ўвагі рэцыпіента. Падтэкст звязаны з абедзвюма пазіцыямі, паколькі ўплывае на ўзнікненне ў свядомасці пэўных асацыяцый, неабходных для ўспрыняцця дадатковых сэнсавых адценняў. Моўныя i нямоўныя сродкі стварэння падтэксту і іх камбінацыі з'яўляюцца хутчэй за ўсё не носьбітамі падтэксту, а толькі стымуламі да яго фарміравання. Ix складаныя дыялектычныя ўзаемасувязі ў розных кантэкстах даюць магчымасць чытачу кожны раз вызначаць новую сэнсавую дамінанту, што прыводзіць да рознага ўспрыняцця і разумення падтэкставых сэнсаў. 
Мастацкі тэкст валодае здольнасцю імпліцытна змяшчаць глыбока асабістыя, не заўсёды даступныя для разумення і поўнага асэнсавання думкі. Мастацкі падтэкст не проста ўспрымаецца, выяўляецца, раскрываецца, ён узнаўляецца ў свядомасці рэцыпіента як вынік яго актыўнай дзейнасці - супрацоўніцтва аўтара і чытача. Ужо сам факт, што важны для разумення ўсяго тэксту сэнс не фармулюецца экспліцытна, а павінен быць атрыманы рэцыпіентам самастойна, надае твору павышаную экспрэсіўнасць. Падтэкст не толькі пашырае і паглыбляе сэнс тэксту, але i змяняе яго, дапамагае больш поўнаму раскрыццю. Як адзначае А. І. Леліс, мастацкі тэкст, "незалежна ад свайго стваральніка, адкрываецца для новых сувязяў, і звядзенне яго сэнсу да аўтарскай задумы збядняе і спрашчае яго. Чытач не толькі ўзнаўляе, не толькі рэканструіруе аўтарскую задуму, але i стварае, канструіруе сэнс па-новаму. Такім чынам, сэнсавая прастора мастацкага тэксту змяшчае ў сабе і інтэнцыі аўтара, і сам тэкст, і яго разуменне чытачом" [Lelis 2011: 9].

Двухпланавая прырода падтэксту накіроўвае на яго найбольш удалае "размяшчэнне" у дыялагічным маўленні. У гэтым плане ўяўляецца слушным меркаванне А. А. Веташкіна, паводле якога “маналог адрозніваецца ад дыялогу большай шматслоўнасцю i дакладнасцю маўлення. У маналагічным тэксце словамі перадаецца ўсё тое, што ў дыялогу інтанацыяй і непасрэдным успрыняццем сітуацыі. Што датычыць унутранага, мастацкага боку, то мадыфікацыі маўленчых формаў задаюць тэмп апавядання, адлюстроўваючы тую ступень увагі і тое значэнне, якое аўтар надае той ці іншай падзеі ў творы" [Wetoshkin A.A. 1999].Ацэньваючы сітуацыю, дыялог фарміруе ў чытача пэўныя адносіны да абмяркоўваемай падзеі, сітуацы, асобы і інш. У дыялогу расстаўляюцца патрэбныя аўтару акцэнты, даюцца характарыстыкі персанажаў, некаторыя адсылкі на крытэрыі, значныя для адэкватнага асэнсавання зместу. Спалучэнне ўнутранага маўлення персанажа 3 аўтарскім забяспечвае суіснаванне двух планаў апавядання адначасова i значна ўзмацняе выразнасць апавядання.

Мэта артыкула - паказаць мастацкі дыялог (дыялагічнае адзінства) У. Караткевіча як сродак перадачы імпліцытнай інфармацыі. 
У мастацкіх творах У. Караткевіча дыялог, па сутнасці, аказваецца сэнсавым цэнтрам, які задае ідэалагічную мадальнасць апавядання, дапамагае вызначэнню напрамкаў яго разгортвання (а значыць, спрыяе ажыццяўленню рэтраспекцыйна-праспекцыйнай сувязі, што вельмі важна для ўсіх тэкставых катэгорый, і асабліва - кагезіi),дапамагае стварыць неабходную аўтару семантычную прастору, у якой будзе разгортвацца дыскурс. Пацвярджэннем імпліцытнай насычанасці дыялога можа быць наступнае дыялагічнае адзінства:

Нарэшие за дзвярамі захадзілі, няўпэунена, нясмела. Пасля пачуўся аднекуль з вышыні сіпаты жаночь голас:

- Хто такія?

- Мы падарожныя, цётухна, пусиіце.

- А иі не з палявання вы часам?

- Якое там паляванне, мокрыя уусе, ледзь на нагах стаім. Дальбог, пусціце нас.

Голас змоукнуў, пасля з нейкімі ноткамі нерашучасиі спытаў:

- А хто ж вы такія? Прозвішча як?

- Беларэикі маё прозвішча. Я з фурманам.

Бабуля за дзвярамі раптам пажвавела:

- Граф Беларэикі?

- Спадзяюся быць графам, - адказаў я з плебейскай непачцівасию да тытулай.

- Голас пасуровеў:

- Ну і ідзі сабе, добры чалавек, туды, адкуль прыйшой. Бачыце вы, ён на графства спадзяециа. Жартачкі начныл! Пайшоў, пайшоў. Пашукай сабедзе-небудзь у лесе бярлог, калі ты такі спрытны.

- Бабуля, - узмаліўся я, - з радасию пашукаў бы, каб не непакоіць людзей, але ж я нетутэйшы, я з павета, заблукалі мы, сухой ніткі няма.

- Прэч, прэч, - сказаў няўмольны голас (У. Караткевіч. Дзікае паляванне караля Стаха).

Працытаваны дыялог, па сутнасці, з'яўляецца неабходным структурным элементам для асэнсавання зместу не проста асобнага апісанага эпізода, але і ўсяго апавядання ў цэлым. Адрозненні ў сэнсавай насычанасці рэплік (“ $A$ ці не з палявання вы часам?” - “Якое там паляванне, мокрыя ўсе, ледзь на нагах стаім. Дальбог, пусціие нас.”) не перашкаджаюць суразмоўцам зразумець адзін аднаго, але ў той жа час паказваюць чытачу, што на самай справе ўдзельнікі дыялогу ўспрынялі толькі знешнюю, слоўную інфармацыю, у той час як для ўспрыняцця міжрадковай (адносна таго, што паляванне - гэта далёка не промысел звяроў ці птушак, а атрад злачынцаў) Беларэцкаму не хапіла пэўных ведаў пра тыя мясціны, куды ён трапіў. 
Імпліцытны інфармацыйны змест выказвання асэнсоўваецца ў выніку далейшага ўспрыняцця тэксту, у выніку ўстанаўлення суадносін паміж аб'ёмам агульных ведаў чытача і пісьменніка і экспліцытным сэнсам выказвання. Так, ужо пасля поўнага прачытання твора становяцца зразумелымі паводзіны ахмістрыні, яе адносіны да людзей з тытуламі і званнямі і суровае ўспрыняцце “плебейскай непачцівасиі да тытулаў”. Аднак пакуль што яе словы не выклікаюць трывогі, хіба што насцярожваюць. Наяўнасць адмоўнага падтэксту пры апісанні названай асобы заўважаецца пры паўторным асэнсаванні: калі чытач даведаецца, якія матывы кіравалі ахмістрыняй, негатыўныя ўспаміны пра першае знаёмства $з$ ёй вяртаюцца і выклікаюць у чытачаадчуванне пастаяннай атмасферы падазронасці вакол названай асобы.

Змяшчэнню падтэкставай інфармацыі ў дыялагічным маўленні спрыяюць разнастайныя стылістычныя прыёмы, якія характарызуюцца магчымай наяўнасцю двухпланавых паведамленняў. У нашым выпадку відавочны ў гэтым плане лексічны паўтор (палявання, паляванне;граф, графам, графства), які дапамагае сканцэнтраваць увагу на дзвюх важных для максімальна поўнага і дакладнага апісання вымарачнасці беларускай шляхты пазіцыях. У прыведзеным прыкладзе паўтор успрымаецца як сродак узмацнення, актуалізацыі, гарманізацы структуры стылізаванага дыялагічнага адзінства, а таксама як сродак экспрэсіўнасці яго індывідуальнага аўтарскага стылю. Вылучэнне слова паляванне паказвае на звязаны 3 ім страх, на існаванне неразгаданай і ад гэтага яшчэ больш жудаснай тайны. Слова граф важнае для ахмістрыні, яна схіляе галаву перад кожным, хто мае гэты тытул, ужо адно толькі пацвярджэнне графства выклікае ў яе жаданне адчыніць дзверы. Аднак выклікае павагу той факт, што Беларэцкі не скарыстаўся незнарокавай падказкай ахмістрыні, што таксама ўплывае на імпліцытнае асэнсаванне яго асобы, у прыватнасці, на яго абыякавыя адносіны да розных тытулаў і званняў.

Абраная аўтарам пытальна-адказавая форма дыялогу таксама невыпадковая. На думку Т. А. Казімірскай, “звычайнае пытанне мае сваю асаблівасць: $з$ яго дапамогай можна больш ці менш дакладна зразумець не толькі тое, што герой хоча ведаць, але і тое, што ён ужо ведае. Звычайнае 
пытанне ніколі не ўзнікае на зусім пустым месцы: у ім імпліцытна заўсёды хаваецца пэўная думка, не выражаная словамі, на аснове якой і задаецца пытанне" [KasimirskajaT.A.1999: 124].Ужо першае пытанне (Хто такія?) выказвае незадаволенасць аўтара рэплікі начным наведваннем. Пісьменнік, на першы погляд, не абцяжарвае сябе падборам слоў для афармлення рэплік ахмістрыні, у той час як рэплікі Беларэцкага вылучаюцца ўвагай да ўключанага ў размову слова, што бачна і ў зваротах (иётухна, бабуля), і ў пацвярджэнні сваёй асобы (мы падарожныя, Беларэикі маё прозвішча, я $з$ фурманам, я нетутэйшы) і ў выражэнні просьбы (дальбог, пусиіче, заблукалі $\mathrm{Mbl}$ ), і у адлюстраванні магчымага варыянта развіцця падзей (з радасию пашукаў бы, каб нем непакоіць людзей).Такая арганізацыя гутаркі імпліцытна паказвае на таго, хто зацікаўлены ва ўздзеянні слоў, для каго правільны іх падбор з'яўляецца сродкам выратавання.

Высновы.Як відаць, падтэкст стылізаванага мастацкага дыялогу мае значныя выразныя магчымасці. У мастацкім творы непасрэднае вуснае маўленне ўзнаўляецца апасродкавана, праз аўтарскую стылізацыю, у апрацаваным выглядзе. Інфармацыя кожнай рэплікі значна шырэйшая, чым яе фактычны змест. Таму ўжо нават выбар дыялагічнай формы падказвае магчымасць размяшчэння ў спецыфічна аформленым кантэксце дадатковай, няяўнай інфармацыі, накіраванай на дадатковае асэнсаванне.

Комплексны аналіз мастацкіх твораў У. Караткевіча дазваляе асэнсаваць імпліцытную насычанасць стылізаваных пісьменнікам дыялагічных адзінстваў, выявіць вобразныя сродкі, якія спрыяюць насычэнню гутаркі дадатковай, скрытай, міжрадковай інфармацыяй i адначасова ўплываюць на фарміраванне індывідуальнага аўтарскага стылю. Значную ролю ў насычэнні мастацкага маўлення імпліцытнай інфармацыяй (у тым ліку дыялогаў) у творчасці У. Караткевіча адыгрывае паўтор. Паўтораныя элементыне толькі звязваюць маўленчыя акты розных камунікантаў, уплываючы на арганізацыю рэплікі субяседніка, але i прымаюць удзел у арганізацы ступеньчатай структуры дыялагічнага адзінства, паказваюць развіццё думкі апавядальніка, удзельнічаюцьу фарміраванні псіхалагічнага партрэта персанажа, акцэнтуюцьувагу на асобнай частцы выказвання і інш. 


\section{REFERENCES:}

1. Wetoshkin,A.A. (1999). Podtekstkakvirasitelnojesredstvojasika, Saransk, 145 s. (Rus)

2. Kasimirskaja, T.A. (1999). Pitanne jak sposab stvarennja padtekstu v dijalagichnaj move, Mogilev, S. 124-126. (Bel)

3. Lelis, E.I. (2011) Teorijapodteksta, Ishevsk, 60 s. (Rus).

4. Nikoljukin, A.N. (2003) Literaturnaja enciklopedija terminov i ponjatij, Moskva, S. 755. (Rus)

Ярмак В.

к.ф.н., доц., Інститут мовознавства ім. О. О. Потебні НАН Украӥни (Украӥна)

Yarmak $V$.

PhD, Docent, O.O. Potebnya Institute of Linguistics of the National Academy of Sciences of Ukraine (Ukraine)

\section{ДОДАТКОВІ ЗАСОБИ ПІДСИЛЕННЯ ВИРАЗНОСТІ ПРЕТЕРИТАЛЬНИХ ФОРМ ДІЕСЛОВА В СЕРБСЬКОМУ ЛІТЕРАТУРНО-ХУДОЖНЬОМУ ДИСКУРСІ}

\section{ADDITIONAL MEANS OF ENHANCING THE EXPRESSIVENESS OF PRETERIT VERB FORMS IN THE SERBIAN LITERARY DISCOURSE}

У статті досліджується непересічна роль другорядних засобів підсилення стилістичної виразності претеритальних форм дієслова в сербському літературно-художньому дискурсі на великому діахронічному зрізі, які, поряд із експліцитними, збагачують їхній образно-експресивний потенціал. До складу таких чинників слід віднести заперечну частку «не»; заперечно-підсилювальну частку «ни»; частки «ено», «ето», «год», «ала»; єднальний сполучник «и»; прислівник «баш»; претеритальні форми, утворені від дієслів із префіксами, або від поліпрефіксованих дієслів тощо. 